\title{
Prevention, Prevention, Prevention
}

\author{
Derek Richards \\ Editor
}

In the last issue we included a commentary on the oral health findings of the Global Burden of Disease study. ${ }^{1}$ This highlighted the fact that untreated decay in permanent teeth was the most prevalent global condition, with $35 \%$ of all ages affected. The impact that this disease has on children in particular is significant and yet it is one area in dentistry where we have good evidence of effective interventions.

Increasing the availability of fluoride is core to caries prevention (see Table 1 for summary of topical fluoride interventions) and supported by the WHO (http:// www.who.int/oral_health/action/risks/ en/index1.html) and the World Dental Federation (http://www.fdiworldental.org/ media/11319/Promoting-dental-healththrough-fluoride-2008.pdf).

In this issue we highlight two recent updates of Cochrane reviews of two particularly effective interventions, fissure sealants $^{8}$ and fluoride varnish. ${ }^{2}$ Both of the updates reaffirm the effectiveness of these interventions. Looking at child caries prevalence in many countries, it could be concluded that fluoride varnish is an underused intervention despite its increasing use for community based prevention programmes (eg Childsmile; www.childsmile.org). With the review suggesting that caries reduction of around $40 \%$ is seen even against background use of fluorides and baseline caries prevalence rates, we should be asking why we shouldn't use it for all patients rather than why we should. However, it is worth noting that the data from the new review show that fissure

\begin{tabular}{|c|c|c|c|c|}
\hline Topical Fluoride & $\begin{array}{l}\text { Number of } \\
\text { studies }\end{array}$ & $\begin{array}{l}\text { Total number of } \\
\text { participants }\end{array}$ & $\begin{array}{l}\text { Prevented } \\
\text { fraction }\end{array}$ & $\begin{array}{l}95 \% \text { Confidence } \\
\text { intervals }\end{array}$ \\
\hline Varnish $^{2}$ & 22 & 12,455 & $43 \%$ & $30 \%-57 \%$ \\
\hline Gels $^{3}$ & 25 & 7747 & $28 \%$ & $19 \%-37 \%$ \\
\hline Mouthrinses ${ }^{4}$ & 36 & 14,600 & $26 \%$ & $23 \%-30 \%$ \\
\hline Toothpastes $^{5}$ & 74 & 42,300 & $24 \%$ & $21 \%-28 \%$ \\
\hline Toothpastes $^{6}$ & 75 & 73,684 & $23 \%$ & $19 \%-27 \%$ \\
\hline $\begin{array}{l}\text { Supplements (tablets, } \\
\text { drops, lozenges or } \\
\text { chewing gums) }^{7}\end{array}$ & 11 & 7196 & $24 \%$ & $16 \%-33 \%$ \\
\hline
\end{tabular}

sealants are more effective than fluoride varnish, even if not regularly monitored and maintained, as they should be.

The UK Departments of Health Preventive Toolkit ${ }^{9}$ and the Scottish Clinical Effectiveness Programmes guideline on the prevention and management of caries in children ${ }^{10}$ both took the view that everyone should be routinely provided with standard prevention advice, with those at increased risk getting enhanced prevention including additional fluoride. If we are to have a significant and continuing effect on reducing the pain and suffering from caries we should all be actively using these evidence-based caries prevention approaches.

1. Marcenes W, Kassebaum NJ, Bernabé E, et al. Global burden of oral conditions in 1990-2010: a systematic analysis. J Dent Res 2013; 92: 592-597.

2. Marinho VC, Worthington HV, Walsh T, Clarkson JE. Fluoride varnishes for preventing dental caries in children and adolescents. Cochrane Database Syst Rev 2013; 11: 7. CD002279.

3. Marinho VC, Higgins JP, Logan S, Sheiham A. Fluoride gels for preventing dental caries in children and adolescents. Cochrane Database Syst Rev 2002; (2): CD002280. Review. PubMed PMID: 12076446.

4. Marinho VC, Higgins JP, Logan S, Sheiham A. Fluoride mouthrinses for preventing dental caries in children and adolescents. Cochrane Database Syst Rev 2003; (3): CD002284. Review. PubMed PMID: 12917928.

5. Marinho VC, Higgins JP, Sheiham A, Logan S. Fluoride toothpastes for preventing dental caries in children and adolescents. Cochrane Database Syst Rev 2003; (1): CD002278. Review. PubMed PMID: 12535435.

6. Walsh T, Worthington HV, Glenny AM, Appelbe P, Marinho VC, Shi X. Fluoride toothpastes of different concentrations for preventing dental caries in children and adolescents. Cochrane Database Syst Rev 2010; 1: CD007868. doi:10.1002/14651858. CD007868. pub2. Review. PubMed PMID: 20091655

7. Tubert-Jeannin S, Auclair C, Amsallem E, et al. Fluoride supplements (tablets, drops, lozenges or chewing gums) for preventing dental caries in children. Cochrane Database Syst Rev 2011; 12: CD007592.

8. Ahovuo-Saloranta A, Forss H, Walsh T, Hiiri A, Nordblad A, Mäkelä M, Worthington HV. Sealants for preventing dental decay in the permanent teeth. Cochrane Database Syst Rev 2013; 3: CD001830.

9. Delivering Better Oral Health. An evidence-based toolkit for prevention - second edition. Department of Health and the British Association for the Study of Community Dentistry 2009.

10. Prevention and Management of Dental Caries in Children. Scottish Dental Clinical Effectiveness Programme. SDCEP 2010 (available at http://www. sdcep.org.uk/index.aspx?o=2332)

Evidence-Based Dentistry (2013) 14, 66. doi:10.1038/ sj.ebd.6400943 